\title{
Forest management issues in a wildland-urban interface: The case of West Bragg Creek Timber Licence in Alberta
}

\author{
by Christopher Opio ${ }^{1}$
}

\begin{abstract}
A wildland-urban interface is a complex and dynamic zone which
makes it a very difficult and uncertain area in which to practice
A wildland-urban interface is a complex and dynamic zone which
makes it a very difficult and uncertain area in which to practice forestry. The difficulty stems from, among other things, lack of an effective two-way communication system between forestry organizations and the affected publics, and from the differential value systems and social standards held by the publics in the wildland-urban domain. The complexity of, and approaches to solving, forest management issues in West Bragg Creek, a wildlandurban setting in Alberta, are examined in this paper, . The public consultation model is proposed and discussed as one strategy to minimize forest management conflicts in West Bragg Creek.
\end{abstract}

Key words: forest management, wildland-urban interface, West Bragg Creek, public consultation model, Alberta L'interface entre le territoire sauvage et le territoire urbain constitue une zone complexe et dynamique qui cree en sorte une zone ou il est tres difficile et peu certain de pouvoir pratiquer la foresterie. La difficulte surgit, entre autre chose, de l'absence d'un systeme de communication efficace bidirectionnel entre les organisations forestieres et les groupes de personnes touchees, et par les systemes de valeur differentielle et les normes sociales de ces groupes du domaine des territoires auvages-urbains. La complexite, et les approches pour faire face aux enjeux d'amenagement forestier de West Bragg Creek, un erritoire sauvage a demi urbain de l'Alberta, sont etudiees dans cet expose. Un modele de consultation publique est propose et discute en tant que l'une des strategies pour minimiser les conflits d'amenagement forestier de West Bragg Creek.

Mots-cles: amenagement forestier, interface du territoire sauvage et urbain, West Bragg Creek, modele de consultation publique, Alberta

\section{Introduction}

Social conflicts over the management of forest resources in public lands in Canada are increasing, especially in wildlandurban interface domains. These conflicts are unavoidable because of the changing value systems of the publics of the 1990s and lack of a broad social consensus about the roles of public forests (Floyd et al. 1996). The presence of a relatively large population at the wildland-rural interface, who may not be directly associated with forest practices (e.g., logging), necessitates a socio-political perspective to forest management on these lands.

This paper focuses on forest management issues in Alberta's West Bragg Creek Timber Licence (WBCTL), a wildlandurban setting which is complex and dynamic. According to O'Shea (1993, page 7), "the wildland-urban interface can be classified as rural, urban or mixed." In the rural classification, residents typically depend on farming and ranching to meet their goals and objectives. Houses in rural areas are commonly scattered or dispersed. Urban classification includes subdivisions or communities where residents generally live in the country, but work in the city. There may also be summer cottages in some of these areas. The mixed classification involves a combination of rural and urban characteristics. West Bragg Creek belongs to this category of classification. Therefore, practising forestry in this zone is difficult and uncertain (Opio 1989).

WBCTL is located approximately 45 kilometres west of Calgary (Fig. 1). It is part of the B7 Forest Management

\footnotetext{
${ }^{1}$ Forestry Program, Faculty of Natural Resources and Environmental Studies, University of Northern British Columbia, 3333 University Way, Prince George, British Columbia, Canada V2N 4Z9
}

Unit. The B7 timber quota provides Spray Lake Sawmills the legal authority to harvest $64.5 \%$ of the allowable cut. This accounts for up to $25 \%$ of the Spray Lake Sawmills' wood supply (McLean Creek Advisory Committee 1996).

The complexity of, and approaches to solving, forest management issues in West Bragg Creek are discussed in

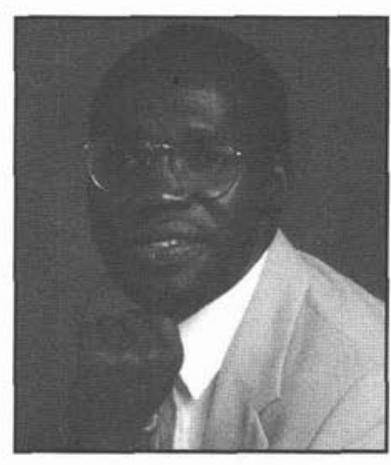
this paper. A background to forestry in Alberta, including historical aspects of forest management issues in West Bragg Creek, are first described to demonstrate forestry problems often encountered at the interface. Second, a potential solution to forest management issues in West Bragg Creek is described. Finally, a public consultation model is proposed and discussed as one strategy to minimize these problems.

\section{Background \\ Forestry in Alberta}

Alberta has a total land area of 64.4 million ha, of which $59 \%$ (38.2 million ha) is forested (Natural Resources Canada 1997). Alberta's forests provide several benefits including timber, wildlife and watershed protection, fur, recreation, employment and tourism opportunities (Environment Council of Alberta 1990).

Management of Alberta's forests is influenced by three factors. First, $87 \%$ of the forested land is provincially owned (i.e., public land). Second, Alberta's forests are rich and diverse in natural resources that satisfy a wide range of biological, economic and social benefits. Third, with proper management, Alberta's forests provide sustainable forest resources use (Environment 


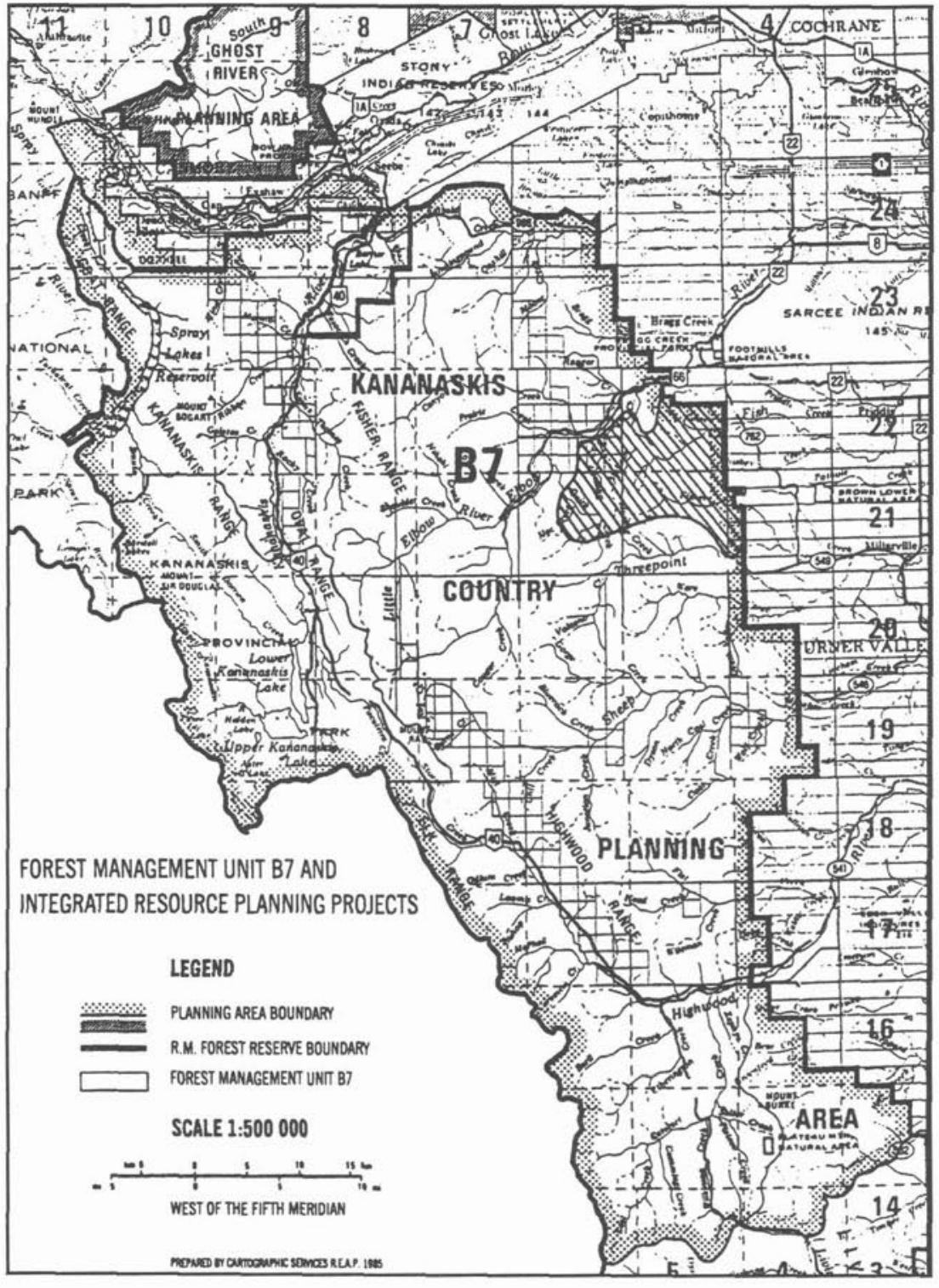

Fig. 1. Map showing B7 Forest Management Unit and Integrated Resource Planning Projects. West Bragg Creek timber licence is part of B7 Forest Management Unit (McLean Creek Advisory Committee 1996).
Council of Alberta 1990). These factors underlie the principal objective for forest management as endorsed by the Alberta Legislature:

\section{"To manage Alberta's forest lands in a manner ensur- ing a perpetual supply of benefits and products while main- taining a forest environment of high quality (McDougall 1986, cited by Environment Council of Alberta 1990, page 1)."}

This objective is broad and as such raises several questions about forest management in Alberta. Some of these questions include: (1) What forest management practices are socially acceptable to Albertans? (2) How can these forests be managed to continuously provide biological, economic and social benefits over time? and, (3) What level of environmental protection is needed to maintain a healthy forest? No single interest group or stakeholder can provide clear and precise responses to these questions. Society at large must confront these questions and determine socially acceptable answers.
Achieving these answers requires extended dialogue among the various interest groups (Environment Council of Alberta 1990).

Management of Alberta's renewable resources (water, air, forests, public land, fish, wildlife and parks) is the primary responsibility of the Alberta Environmental Protection Department. The Alberta Government, through the Department of Environmental Protection's Land and Forest Service ${ }^{2}$, is responsible for forest management which includes timber harvesting, reforestation, livestock grazing, control of forest fires and pest management, and outdoor recreation (McLean Creek Advisory Committee 1997). The Alberta Land and Forest Service issues dispositions (timber management agreements, quota certificates, timber licences, commercial timber permits and local timber permits) and sets ground rules for timber harvesting. It approves company harvesting plans and promotes watershed protection.

\footnotetext{
${ }^{2}$ Alberta Land and Forest Service was formerly known as Alberta Forest Service (McLean Creek Advisory Committee 1998)
} 


\section{History of forest management in West Bragg Creek Timber Licence}

WBCTL is characterized by two dominant tree species, lodgepole pine (Pinus contorta) and white spruce (Picea glauca), occupying $95 \%$ and $5 \%$ of the forest cover, respectively. Common wildlife species include deer (Odocoileus hemionus and $O$. virginianus), moose (Alces alces), and elk (Cervus elaphus). WBCTL represents a typical sub-alpine/boreal forest condition: well drained glacial deposits with undulating terrain characteristics (Alberta Forest Service 1989).

During the late 1970 s when the Alberta economy was at its "boom" stage because of petroleum and natural gas explorations, many people chose to establish homes on acreages adjacent to the "Green" area (public, Crown lands, mostly forested (Environment Council of Alberta 1990)) in West Bragg Creek (Alberta Forest Service 1989). Some of these people work in Calgary, but live in West Bragg Creek. Within the framework of the 1977 East Slope Policy and the Kananaskis Country Integrated Resource Plan, a decision was made by the Alberta government to manage the timber resource of that portion of Kananaskis Country on a sustained yield basis. The decision included the formulation of a detailed timber management plan with appropriate Allowable Annual Cut (AAC) reduction to conform with recreational requirements. The 20 year harvest sequencing of the plan identified the West Bragg Creek as the first cut plan area.

The timber license was issued to Spray Lake Sawmills (1980) Limited, the quota holder for the area. A preliminary Annual Operating Plan (AOP) was submitted considering the following alternative uses of the area: cross-country ski trails primarily established on past harvesting access and seismic lines in the area, hiking and equestrian use, impact on wildlife, aesthetic potentials of the area in consideration of other uses and the area's overall scenic potentials, increased traffic on weekends (skiers versus logging trucks and hauling through the hamlet of Bragg Creek), and the impact on the two grazing allotment permittees. Representatives from the Spray Lake Sawmills, Alberta Parks and Recreation, Alberta Transportation, Fish and Wildlife Division, Kananaskis Country Departmental Committee, Kananaskis Country Citizens Advisory Committee, and Ranchers were involved in drafting the AOP. Modifications to the AOP were made to accommodate the interests of the various stakeholders involved. The AOP was approved and logging commenced.

Local residents became aware of the harvesting program, and as a result, the Bragg Creek Select Citizens Committee on Logging was formed to operate as an opposing force to the proposed logging. Some residents were not satisfied with the AOP formulation process, particularly the general meeting held with the Forest District staff, and the public meeting with senior Alberta Forest Service management. The concerned residents felt that they were betrayed or neglected. Consequently, a public meeting was then held in West Bragg Creek, chaired by a representative from the Alberta Forest Service. During the meeting, the harvest plan was presented to the public for discussion. However, negative and emotional feedbacks were prevalent. Major areas of concerns were: (1) the public were not informed; (2) logging trucks were noisy and presented a public safety hazard; (3) logging trucks would destroy the highway and access road; (4) logging would destroy aesthetics and character of the cross-country ski area; and (5) noise from the logging activities would directly affect several local residents and disturb their environment of solitude and peace.

Through meetings and field trips, only minor modifications were made to the harvest design. Concerns expressed at the meetings were addressed, and a consensus to commence logging in WBCTL was reached. Logging proceeded without incident through the 1986-1987 season. In August of 1987, public meetings were held in the West Bragg Creek and Turner Valley communities. Representatives of interest groups, including the affected citizens, government agencies, and known forest users were involved in the meetings to review the entire 20 year harvest schedules in WBCTL. Although there was a general agreement for the need for forest resource management in the Kananaskis Country, a few residents still opposed harvesting in the area.

Opio (1989) summarized major interests and concerns of West Bragg Creek residents (Table 1). Recreation and wildlife protection were considered the most important attributes in West Bragg Creek. Clearcut logging in West Bragg Creek was a controversial issue. Some people opposed it (for reasons such as negative visual impacts and resource depletion), while others favoured it (for reasons such as clearcutting improves deer browse). A significant number of West Bragg Creek residents were willing to learn more about forest management practices, especially through government brochures, seminars and workshops. They also viewed the public participation process as a necessary tool for them to get involved in the Alberta Forest Service's decision-making process regarding logging or any other aspects of forest management and development initiatives in West Bragg Creek.

After a careful analysis of the public concerns about logging in WBCTL, Opio (1989) concluded that these concerns were due, in part, to lack of effective communication among the Alberta Forest Service, Spray Lake Sawmills and West Bragg residents. Furthermore, the views held by the residents of West Bragg Creek, for or against logging in the area, were directly related to occupational status and value systems of the residents. For example, a business executive or professional living in West Bragg Creek, but working in Calgary, was more likely to oppose logging in West Bragg Creek (e.g., for noise from logging trucks) than a forest worker living in West Bragg Creek.

Logging will begin again in WBCTL in the near future (McLean Creek Advisory Committee 1997), and despite increasing efforts being made by the Alberta Land and Forest Service and Spray Lake Sawmills to ensure that forest resources are properly managed in WBCTL, public concerns about logging still exist in West Bragg Creek (McLean Creek Advisory Committee 1998).

\section{A Potential Solution to Forest Management Issues}

Forest management is considered as a set of actions which involves controlling the interventions in, and the natural disturbances to, the forest, based on the interests that the forest owner or society have in the forest (Baskerville 1978, Leuschner 1990). Interventions are human actions taken to influence the dynamic development of the forest. These actions include harvest scheduling, prescribed burning, forest renewal and tending. Natural disturbances to the forest include fire, insect attack, disease and severe weather conditions. Forest managers 
Table 1. Public attitudes towards forest management practices in West Bragg Creek Timber Licence ${ }^{1}$

Question asked
How important are forests to you in West Bragg Creek?
Do you favour logging in West Bragg Creek Timber Licence?
How would you describe your working relationship with: - Local Forest Rangers?

How often does Alberta Forest Service ${ }^{2}$ inform the people of West Bragg Creek about its

How often does Alberta Forest Service ${ }^{2}$ inform the people of West Bragg Creek about its logging plans?

How should Alberta Forest Service involve the people of West Bragg Creek in the formulation of its forest management plans? (Rank the method as good or bad)

Describe your attitude towards clearcutting as a method of logging in West Bragg Creek Timber Licence.

Describe your knowledge of forest management practices in West Bragg Creek Timber Licence.

Are you willing to learn about forest management practices in West Bragg Creek?

Response

Important

Oppose $\quad 45 \%$

Favour $\quad 36 \%$

Good $70 \%$

Fair 20\%

Good $\quad 45 \%$

Fair $\quad 30 \%$

Sometimes $\quad 57 \%$

Never $36 \%$

Best methods

- Community meetings $\quad 58 \%$

- Workshops 28\%

Worst methods:

- Television $34 \%$

- Radio $32 \%$

- Newspaper 25\%

Oppose $60 \%$

Favour $24 \%$

Good $51 \%$

Poor $\quad 49 \%$

Yes $\quad 98 \%$

No $2 \%$

Which methods should Alberta Forest Service use to educate the public in West Bragg Creek about forest management practices in the region? (Rank the methods as good or bad)

Good methods:

- Public meetings

(seminars and workshops)

Bad methods:

- Radio

- Television

Are you willing to participate in a public participation process organized by Alberta Forest Service?

Yes

No

${ }^{1}$ Based on the field study (Opio 1989) in West Bragg Creek. The study employed a simple random sampling approach and questionnaires. The sample size was $20 \%$ of the population of West Bragg Creek residents.

${ }^{2}$ Alberta Forest Service is now called Alberta Land and Forest Service (McLean Creek Advisory Committee 1998).

intervene in forest dynamics because of their desire to obtain some ecological and silvicultural benefits, economic return, or personal satisfaction. Forest managers are concerned, among other things, with knowing output schedules and cash revenues, wildlife management, fishery management, recreation and aesthetics management, water resources management, work loads and costs associated with forest management practices (Leuschner 1990).

A major problem in forest management is to forecast the changes that will occur in the forest, especially to predict those changes that are delayed, or lagged in time. Consequently, the time horizon for forest management decisions is of the order of 50 to 100 years (Baskerville 1978). This means that a decision today to take some action (e.g., cut) in the forest, or not take any action (i.e., not cut), influences the course of forest development for 50 to 100 years. The maximum biological impact of the decision cannot be seen except by observing forest performance over this time period. Furthermore, because of the 50 to 100 year time horizon, decisions made today and influenced by today's society, may not meet the desires of society in 50 to 100 years because of changes in values and expectations.

Forest management frequently involves uncertainty because social, economic and ecological consequences of management actions cannot be predicted precisely. As in many other resource management problems, there are some components of forest management, notably societal needs or attitudes or public expectations, which are not quantifiable and are not always under the jurisdiction of the forest manager (Thompson and McKay 1984, Jones and Greig 1985).

Foresters typically live and work within organizations. Their work and opinions may be strongly influenced by the purposes and interests of their own organizations. The goals and objectives of the residents of the West Bragg Creek may not be consistent with those of Spray Lake Sawmills and the Alberta Land and Forest Service foresters. For example, the concern over forest aesthetics in West Bragg Creek, due to areas of clearcut timber, is a social preference (value system). People with that kind of concern might not be pacified by the evidence that such methods of logging may have been economically or silviculturally favourable.

Measurement of social acceptability of a forest management project in WBCTL is a difficult task, partly due to variations among West Bragg Creek residents. To deal with this issue, Spray Lake Sawmills and the Alberta Land and Forest Service should maintain effective public consultation programs, involving the affected and interested publics as early as possible, during harvest planning and implementation. This approach may minimize potential destructive social conflicts and generation of confrontational attitudes (Thompson and McKay 1984). 
Spray Lake Sawmills and the Alberta Forest Service should also jointly develop an ecosystem-based forest management (Slocombe 1993b, Atkinson 1984, Grumbine 1994, Sedjo 1995, Boise Cascade Corporation 1996, Mitchell 1997) framework not only for WBCTL, but for the entire B7 Management Unit. The framework should reflect three things. First, it should be based on applied ecological principles (Perry and Amaranthus 1997). Second, it should have the mechanisms which involve the public in its design process and implementation. Third, the framework should be both strategic and tactical, and should be built on the principle of adaptive management (Walters and Hilborn 1978, Walters and Holling 1990, Baskerville 1984, Schmeigelow and Hannon 1993, Taylor et al. 1997) which considers complex interactions among the ecological, economic and social components of B7 Management Unit. Taylor et al. (1997, pages 1and 2) defined adaptive management as:

"A formal process for continually improving management policies and practices by learning from their outcomes. Adaptive management involves: (1) explicitly recognizing that there is uncertainty about the outcome of management activities; (2) deliberately designing management policies or plans to increase understanding about the system, and reveal the best way of meeting objectives; (3) carefully implementing the policy or plan; (4) monitoring key response indicators; (5) analyzing the outcomes, considering the objectives and predictions; and (5) incorporating results into future decisions. Adaptive management requires managers and decision-makers who are willing to learn by doing, and who acknowledge that making mistakes is part of learning."

Integrating social, economic and biological factors into forest management decisions is an important step, but does not itself lead to sustainable forest management. Kessler (1995) outlined five conditions which must be met to achieve better forest management: (1) forest practices (logging, planting, etc.) must be socially acceptable and ecologically sound; (2) field workers must have adequate information to ensure that forest practices are appropriately implemented on the ground; (3) forest practices must be monitored and enforced for compliance; (4) forest practices must be rigorously and continuously tested and evaluated; and (5) there must be a feedback mechanism so that the results of forest practices are adjusted and refined over time to ensure better forest management. Canadians are looking for new models (approaches) to sustainable forest management. An ecosystem-based forest management (Kohm and Franklin 1997) model appears to be a promising alternative.

Several models exist in the literature that deal with public participation (involvement) in resource management decisions. Floyd et al. (1996), for example, discussed the Alternative Dispute Model (ADR), a method for assessing negotiations and mediation in forest resource conflicts. They argued that resource managers should not consider ADR as a recipe for conflict resolution because the kinds of resources involved in the dispute influence the participants' perception of quality of resolution, whether or not the settlement is environmentally sound, and the time it takes to reach agreement. Nixon (1993) argued that a true consensus, principled negotiation and shared decision approach to minimize conflicts in forest management decisions should ensure two things. First, interest groups should be given a fair chance to participate in a shared decision-making process. Second, public participation should be an inclusive process. The Coordinated Resource Management Model (CRM), involves teams of agency representatives, landowners, interest group representatives, and members of the general public to collectively determine acceptable management practices (Moote and McClaran 1996). However, the implementation of the CRM model has sometimes encountered legal and philosophical barriers (Amy 1990, Meidinger 1997). More recently, an ecosystem-based approach to forest planning has been undertaken by Slocan Forest Products Limited, Slocan Division, to develop a sustainable forest management framework for the Bonanza Face Planning Area at the northern end of Slocan Lake. Concepts of landscape design, ecosystem-based management, and adaptive management have been included in the framework. It is a tactical, sub-landscape unit or watershed level plan which integrates higher level concerns with ecological, economic and social factors into a guiding strategy for operational, stand level development plans (Slocan Forest Products Ltd. 1998). Similarly, McLean Creek Advisory Committee (1998), in consultation with Spray Lake Sawmills, the Alberta Land and Forest Service and stakeholders in McLean Creek, Alberta, has also proposed a process to develop the McLean Creek Harvest Plan which will be based on an interdisciplinary approach to forest management.

There is no simple solution to forest management problems in the wildland-urban interface. The most desirable strategy to follow is that forestry management decisions must be reached after extended and careful involvement of many publics, many small adjustments and compromises to reach an overall inclusive program of action (Clawson 1984).

The public consultation model (Fig. 2), proposed and discussed in this paper, is one strategy to minimize the conflicts among Spray Lake Sawmills, Alberta Land and Forest Service, and West Bragg Creek residents. It differs from the standard approach to forest management because it addresses key responsibilities (obligations) of forest managers to the public. The model also emphasizes an ecosystem-based approach to forest management, the principle of adaptive management, and greater cooperation and open dialogue among interest groups (stakeholders).

\section{The Proposed Public Consultation Model}

The public of the 1990s is suspicious about the ways public forests are managed. Misunderstandings exist between foresters and the public, partially due to public misconceptions about what foresters do. Quite often negative views are expressed in the newspapers, popular magazines, and over television and radio. As foresters, we must realize that the public has the right to know how and why public forests are managed.

Technical and scientific knowledge are essential, but are insufficient tools for better forest mangement. To practice effective forest management, a forest manager must use the combined skills of a public relations practioner, communicator, sociologist and psychologist (Dickson 1983). There are three types of tests that every forester has to pass in order to become a good forest manager. First, a forester must be seen by the public as honest and trustworthy. Second, the forester must be able to communicate effectively with the public. 
PHASE 1

ESTABLISH PRINCIPLES FOR PUBLIC INVOLVEMENT PROCESS

- The Trust Principle

- The credibility theory

- The transaction analysis theory

- The polarization theory

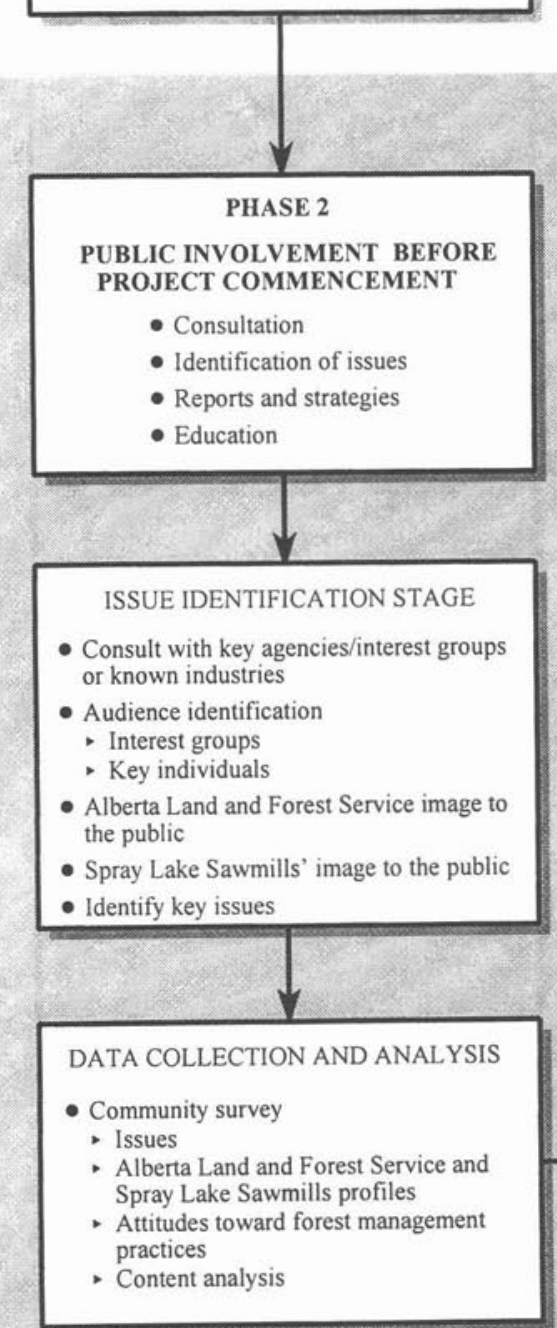

DEVELOP PUBLIC INVOLVEMENT STRATEGIES

(Agreed on strategies)

- Review with Alberta Land and Forest Service and Spray Lake Sawmills' senior management

Purpose:

- To inform and involve the public

Public involvement strategies:

- Public meeting, or

- Round tables (key interest groups)

Goals:

- Need response to issues identified

- Possible forest management strategies

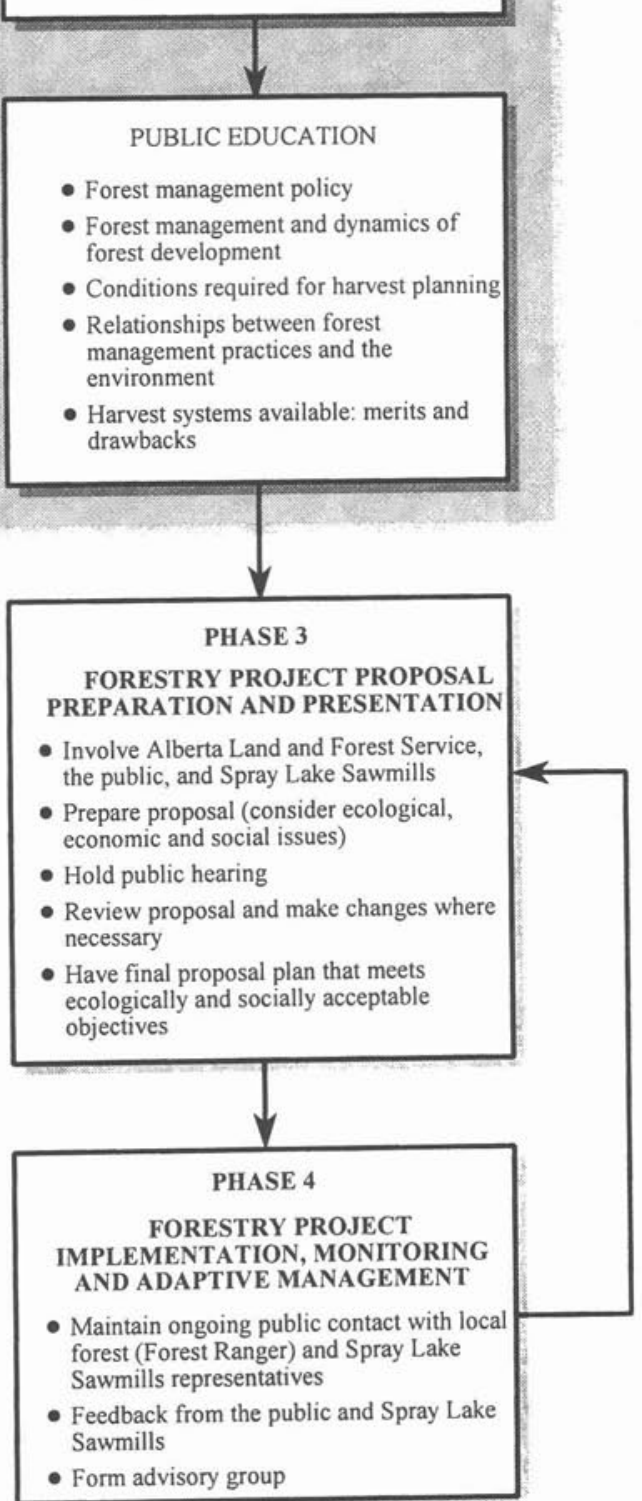

Fig. 2. The public consultation model. 
Third, the forester must explain to the public what forest management is, the biological, economic and social issues involved in forest management, the compromises that are made in forest management decisions, and the reasons for human interventions (e.g., logging) in public forests.

The public consultation model proposed in Fig. 2 has four main phases. Phase one emphasizes the need for a forest manager to be viewed by the public in West Bragg Creek as someone that is honest, trustworthy, and credible. Phase two addresses the underpinnings of public involvement in forest management in WBCTL. Phase three deals with forest management project proposal preparation and presentation, involving Spray Lake Sawmills, Alberta Land and Forest Service, and the public in West Bragg Creek. Phase four addresses the implementation and monitoring of the forestry project in WBCTL. An adaptive management approach should be maintained during the project implementation and monitoring. The basic assumption is that ecological, social and economic systems are dynamic. Thus, any project (plan) developed must be able to adapt over time to accommodate relevant changes. For example, the plan may need to be adapted to accommodate changing forestry legislation, management policies or socioeconomic realities (Slocan Forest Products Ltd. 1998). Forest managers from Spray Lake Sawmills and Alberta Land and Forest Service who are directly responsible for developing harvesting plans and management of WBCTL should consider all the four phases of the proposed model. The four phases, for ease of understanding, are discussed below under two broad categories: (1) honesty, trust and credibility; and (2) public involvement, project development and implementation, and adaptive management.

\section{Honesty, trust and credibility}

Honesty, trust and credibility relate to the public perception about forest managers. Is a forest manager seen by the public as someone credible, honest and trustworthy? The public expects forest managers to be honest, competent, accountable and transparent in managing forest ecosystems to meet social and economic benefits of forest dependent communities (Fortmann 1995). According to Dickson (1983), the development of a favourable public image is the result of good public relations (PR).

Cutlip and Center, as cited in Dickson (1983, page 174) defined $\mathrm{PR}$ as "the planned effort to influence public opinion through good character and responsible performance based upon mutually satisfactory two-way communications." The main purpose of PR is to effectively communicate to people. The public in West Bragg Creek have to know and understand what a forest manager does in WBCTL. The forest manager should be aware of how the residents of West Bragg Creek view him/her. If a forest manager does not show objectivity and independence of thought, he or she will not be accorded a professional respect. The forest manager's character and reputation (i.e., how the public in West Bragg Creek perceive him or her) are also important aspects of PR. If character and reputation do not match, then the forest manager has to work at improving his or her image. Dickson (1983) views PR as a balance between withdrawals and deposits in the Bank of Goodwill. In the Bank of Goodwill, withdrawals are rudeness, mistakes and dishonesty. The forest manager must know that these withdrawals should not exceed the deposits in the form of good
ALBERTA LAND AND FOREST SERVICE AND SPRAY LAKE SAWMILLS LIMITED

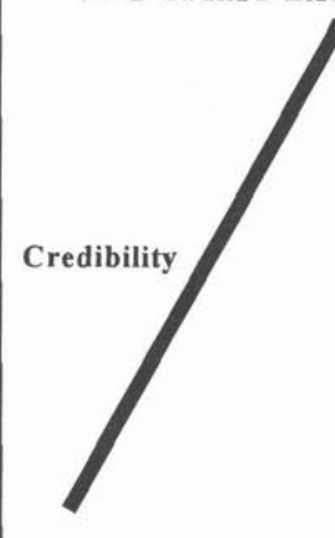

PUBLICS

CONCEPT

(An issue of

Acceptance

concern)

Fig. 3. The credibility theory (adapted from USDA Forest Service 1978).

work done and recognized. When good credit has been built in the Bank of Goodwill, it is crucial not to go bankrupt. The forest manager must build up this kind of credit by being professional in what he or she does.

According to the USDA Forest Service (1978), the trust principle holds that the road to organizational excellence is paved with trust and respect. It provides an opportunity for people to candidly agree and/or disagree without fear of organizational or personal reprisal. The trust principle is built on credibility, transactional and polarization theories.

Credibility theory demonstrates a network of relationships among the organizations (in this case Alberta Land and Forest Service and Spray Lake Sawmills), the public and an issue of concern (Fig. 3). The rationale behind this network rests on the assumption that how a certain public accepts a concept asserted by the source depends on how credible the source is with the public on the topic (USDA Forest Service 1978). The more credible the Alberta Land and Forest Service and Spray Lake Sawmills are, the more their assertions are likely to be accepted. An assertion could be in the form of a plan, proposal, policy or decision. An assertion which the residents of the West Bragg Creek disagree with might be better accepted if the source is credible.

Transactional theory deals with the response attitude. Interactions between public groups and the organization (Alberta Land and Forest Service or Spray Lake Sawmills) is likened to attitudes assumed in conversations between parent and child (Harris 1967). In the example of a child-parent relationship, if either the organization or the public in West Bragg Creek treats each other in a paternalistic or authoritarian way, frustrations, emotional and unfavourable attitudes toward the organization or the public are some of the behavioural responses that are likely to occur. In this kind of relationship, no communication occurs (Fig. 4a). A better relationship exists when the Alberta Land and Forest Service or the Spray Lake Sawmills and the residents of West Bragg Creek relate to each 


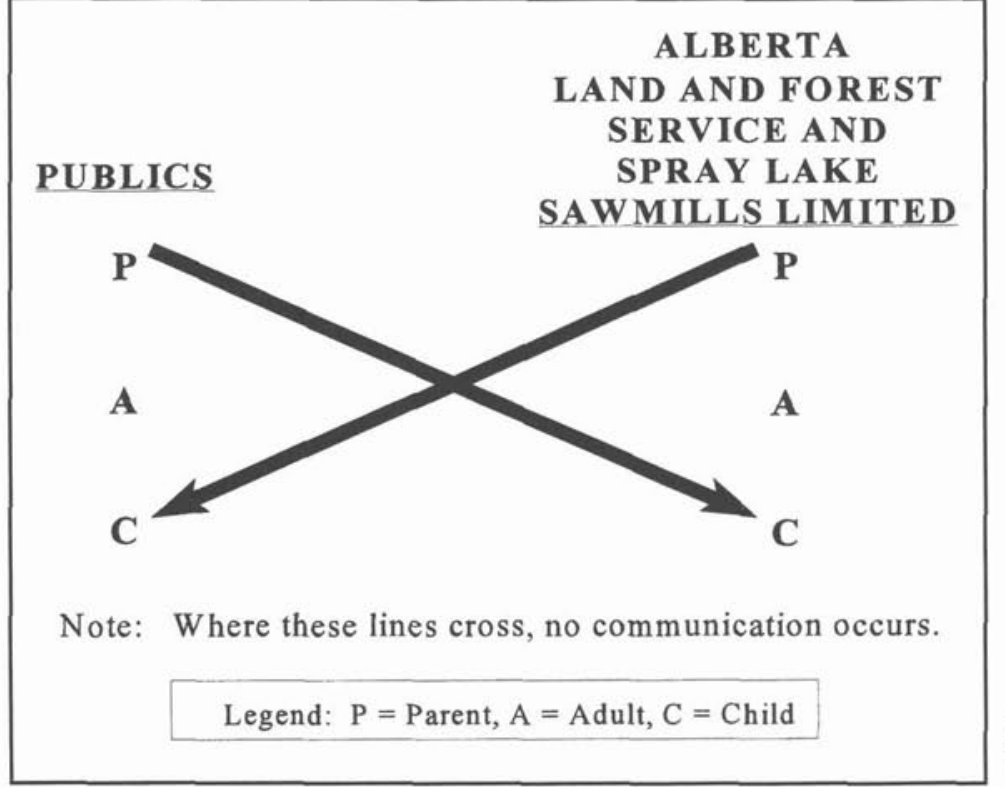

Fig. 4a. Worst relationship between forestry organization and the public.

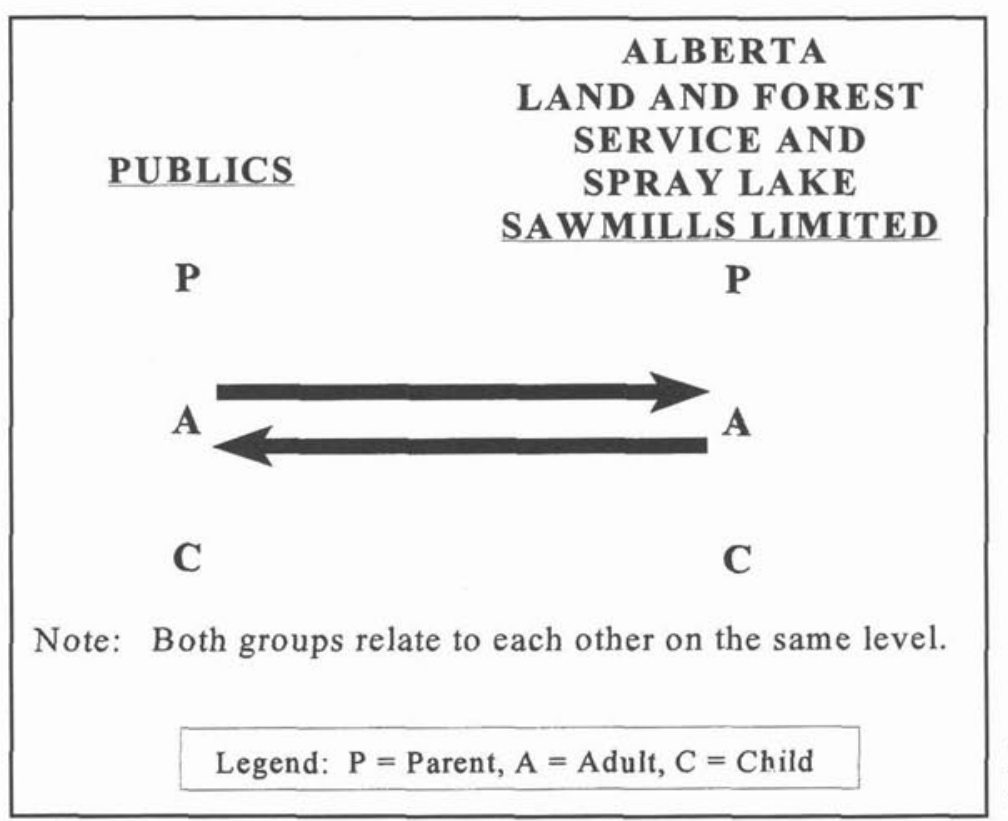

Fig. 4b. Best relationship between forestry organization and the public (adapted from Harris 1967). other in an "adult-adult" relationship: a two-way communication system (Fig. 4b) to build an environment of trust.

The polarization theory refers to taking a firm stand on an issue (USDA Forest Service 1978). However, taking a firm position on an issue requires understanding the problem and how to deal with it. For example, if it is known that the public in West Bragg Creek are opposed to logging in WBCTL solely due to their social preferences, then the forest managers from the Alberta Land and Forest Service and Spray Lake Sawmills should make it clearly known to the public that logging or other forest management decisions in WBCTL will be based on sound ecological principles, economic factors, and social acceptability. Furthermore, the Alberta Land and Forest Service and Spray Lake Sawmills should make it known to the public in West Bragg Creek that forest management decisions involve compromises (e.g., the public, the Alberta Land and Forest Service and Spray Lake Sawmills will have to give up something),

In order to convey an effective message about the management of WBCTL to the public in West Bragg Creek, the forest manager needs to know something about communication theory as discussed in Fazio and Gilbert (1981). The goal of the communication should be to transfer facts, feelings and ideas from the forest manager to the residents in such a way that the forest manager's message is clear to the residents, and the responses from the residents are clear to the forest manager.

Before forest management proposals by the forest manager are transferred to the West Bragg Creek residents, those proposals have to be put in a form that can be transmitted. Quite often this involves the use of words, written or spoken, frequently supplemented by graphic or photographic images. Once the message is formulated, the appropriate communication chan- 
nel (face-to-face, newspapers, television, etc.) has to be chosen.

The forest manager must have good knowledge of biological, economic and social aspects of forest management. The affected residents must also be provided with the opportunity to learn or be made aware of forest management policy, conditions usually required for harvest planning, harvesting systems and the environment, forest management and dynamics of stand development, and the merits and drawbacks of harvesting systems available for WBCTL. The intention of Spray Lake Sawmills and the Alberta Land and Forest Service must be to develop a two-way, consensus building approach with the affected residents.

\section{Public involvement, project development and implementation, and adaptive management}

Spray Lake Sawmills and the Alberta Land and Forest Service forest managers should consult with key agencies, interest groups, and known industries in West Bragg Creek to determine forest management issues which are of concern to West Bragg Creek residents. Such consultation may also enable the forest managers to identify the most relevant publics (i.e., interest groups and key individuals) in West Bragg Creek. Usually a public is considered relevant to the concerns of Spray Lake Sawmills and the Alberta Land and Forest Service on the following basis: does Spray Lake Sawmills or the Alberta Land and Forest Service (or may Spray Lake Sawmills or the Alberta Land and Forest Service in future) have some effect on the public, or does the public (or may the public in future) have some effect on Spray Lake Sawmills or the Alberta Land and Forest Service? Spray Lake Sawmills or the Alberta Land and Forest Service should then prepare a report (working paper) covering the issues of concern identified during consultations. Such a report is useful in designing data collection procedures and analysis, and management strategies.

Data collection and analysis, sometimes referred to as a communications audit (Phillips 1985), provide insights into the efficiency of the organization's communication strategies and practices. A communications audit can reveal information of a more sensitive nature, such as the existence of public frustrations, concerns, attitudes, and the organization's image, strengths and weaknesses. The communications audit is normally done through interviews (face-to-face, telephone or questionnaire). Data collection can be both internal and external. Internal data collection provides evaluations of the "inside" audiences, such as the employees within the organization, or the organization's management style. External data collection provides evaluations of the way outside publics perceive the organization. Spray Lake Sawmills and the Alberta Land and Forest Service forest managers should carefully (e.g., no leading questions, impartial data collection, etc.) conduct community surveys (i.e., external data collection) to determine: (1) how West Bragg Creek residents perceive forest management practices in WBCTL; (2) what and which groups of people like/ do not like; (3) what the Alberta Land and Forest Service, Spray Lake Sawmills and the residents are willing to give up; and (4) appropriate mechanisms for public involvement in the design and implementation of forest management plans.

Following the data collection and analysis phase, a working paper (report) outlining the results of the survey must be prepared. The report should serve as a feedback to Spray Lake Sawmills, the Alberta Land and Forest Service, the affected residents, and other stakeholders. Based on the report, Spray Lake Sawmills and the Alberta Land and Forest Service should be able to choose appropriate public consultation strategies (e.g., a public meeting or round table meeting with key interest groups). The goal is to seek response to forest management issues identified and for Spray Lake Sawmills and Alberta Land and Forest Service to have a more open public consultation approach, and for Spray Lake Sawmills and Alberta Land and Forest Service to retain credibility.

Public participation (involvement) is the process by which the views of all parties interested in an agency's decisions are integrated into an agency's decision-making process (Roberts 1988). If public participation is viewed as an expensive hindrance, that would be a self-fulfilling prophecy (Thompson and McKay 1984). However, if it is viewed as an exercise in predicting, avoiding or minimizing problems, and a chance to extract resources that might not be available, the money would generally be well spent and the results are likely to be productive.

An effective public participation program should have the following key attributes (Krawetz et al. 1987):

(1) The affected publics must be included before final plans are drawn up and they should feel that they are included in the program, and the parties involved must be receptive and committed to the public participation program.

(2) Change in public values is a continuous process. Therefore, each public participation should be entered into with a clear definition of goals and objectives, and identification of affected publics, so that an appropriate choice of methodologies can be made.

(3) Negotiative public participation strategies, such as alternative conflict resolution, are more effective and productive techniques in dealing with conflicts than authoritarian approaches where the decisions are made and then announced to parties involved. Involving the public in a negotiative process may lead to early conflict resolution and acceptance of the proposal.

(4) Public participation is an expensive process. Therefore, a great deal of planning and expertise is required to engage in a successful and valid participation program.

(5) Public participation should never be entered into as a public relations exercise since the entire purpose of the program is for a two-way communication. The critical thing to remember is that each person and situation is different, and no one technique is best (Roberts 1988, Grima 1985). Once this is recognized, unique programs can be designed for each proposal by the proponents and agencies, and the results will very likely enhance forestry project planning and public acceptance in the future.

Spray Lake Sawmills and the Alberta Land and Forest Service should provide, through appropriate and cost efficient mechanisms, the opportunity for the affected residents in West Bragg Creek to learn about basic principles of forest management, including the factors and compromises involved in designing a logging plan. This approach may enhance general public understanding of basic forest management strategies in WBCTL. The approach may also minimize potential forest management conflicts in West Bragg Creek.

Preparation of a forestry project, such as logging, should be done with inputs from Spray Lake Sawmills, Alberta Land and 
Forest Service, affected residents and the interest groups in West Bragg Creek. A public hearing and public participation (involvement) should be held following the preparation of the proposal. The goal is to have a final logging plan which is ecologically sound and socially acceptable in West Bragg Creek.

Spray Lake Sawmills and the Alberta Land and Forest Service should maintain ongoing public contact with local representatives of interest groups in the West Bragg Creek. Such contact should provide forest managers the feedback from field operations, whether or not they are being conducted as stated in the plan, or whether or not slight alterations are needed in the plan as the project commences. Most importantly, maintaining such contact should allow the forest manager to follow the complexities of local problems in order to develop appropriate feedback systems for decision evaluations. This is an adaptive management approach as described earlier in this manuscript. An advisory group should also be formed as part of the feedback mechanisms linking the public, the Alberta Land and Forest Service, and Spray Lake Sawmills.

Spray Lake Sawmills, Alberta Land and Forest Service, and the affected publics in West Bragg Creek should engage in a "joint learning relationship" or a two-way flow of knowledge and ideas of how to deal with forest management issues in WBCTL. Without this relationship, none of the parties are likely to be satisfied. The affected publics may not receive relevant information on forest management practices (for example, the reasons for and the merits of logging) in their region. Spray Lake Sawmills and the Alberta Land and Forest Service may not receive the satisfaction of seeing their management plans and research, which have absorbed limited budgets, contribute to forestry, economic and social development in West Bragg Creek.

\section{Conclusions}

Management of WBCTL is a difficult task, primarily due to lack of an effective communication among forest managers of Spray Lake Sawmills, the Alberta Land and Forest Service and the affected publics, lack of public understanding of forest management principles, and the complexity of social preferences held by the residents of West Bragg Creek.

Public understanding is affected by internal and external obstacles. Internal barriers normally occur within an organization as a result of many factors, including: (1) failure to admit mistakes either during the project planning or implementation process; (2) failure to correctly forecast and disclose possible effects of management decisions on the affected parties; (3) inadequate leadership in dealing with controversial issues (e.g., clearcutting); and (4) inadequate quantity and quality of interaction with forest users. External barriers frequently arise due to rapid changes in public values. The public communication approach presented above is comprehensive and may be viewed as a costly model. However, forest managers from Alberta Land and Forest Service and Spray Lake Sawmills should consider the model because it may save costs in the long run by avoiding conflicts and related costs (both monetary costs and public relations/legal costs). The implementation of the model depends on the availability of financial or human resources, the scale of the forest project and the sensitivity of public concerns about forest management practices. For example, if the public concerns or issues related to forest management practices in the wildland-urban interface are known or are not sensitive, there is no need to conduct a community survey. Spray Lake Sawmills or the Alberta Land and Forest Service can simply conduct public involvement programs during project proposal preparation. If, however, the public concerns are sensitive or inadequately known, then all the four phases of the model should be considered.

\section{Acknowledgements}

The author would like to thank Winifred Kessler, Kathy Lewis, and Annie Booth for their useful comments, the anonymous reviewers and the Associate Editor of this journal for their constructive comments. Special thanks to Richard Roberts for his critical critique of the public consultation approach discussed in this manuscript. The author is also grateful to Richard Revel, Tomson Ogwang, and Khasa Phambu for their thoughtful comments on the manuscript, and to Lois Crowell for typing the figures.

\section{References}

Alberta Forest Service. 1989. West Bragg Creek timber harvesting. Alberta Forest Service, Edmonton, Alberta.

Amy, D. 1990. Environmental dispute resolution: the promise and the policy. In N.J.Vig and M.E. Kraft (eds.). Environmental Policy in the 1990's: toward a New Agenda. pp. 211-234. CQ Press. Washington, D.C.

Atkinson, W.A. 1984. Managing the urban/forest interface: a view from forest industry. In G.A. Bradley (ed.). Land use and forest resources in a changing environment. pp. 20-30. University of Washington Press, Seattle.

Baskerville, G.L. 1978. Forest dynamics and management decisions. University of New Brunswick, Fredericton.

Baskerville, G.L. 1984. Adaptive management: wood availability and habitat availability. For. Chron. 70: 171-5.

Boise Cascade Corporation. 1996. Forest ecosystem management: a graphical overview. Boise Cascade Corporation, Timber and Wood Products Division, La Grande, Oregon.

Clawson, M. 1984. The urban/forest interface: summary observations and research needs. In G.A. Bradley (ed.). Land use and forest resources in a changing environment. pp. 198-211. University of Washington Press, Seattle.

Dickson, A. 1983. The forester as salesperson. For. Chron. 59(4): 174-176

Environment Council of Alberta. 1990. Our dynamic forests: the challenge of management. ECA90-PA/CS-S15. Edmonton, Alberta. Floyd, D.W., R.H. Germain, and K. Horst. 1996. A model for assessing negotiations and mediation in forest resource conflicts. J. For. 94(5): 29-33.

Fazio, J.R. and D.L. Gilbert. 1981. Public relations and communications for natural resource managers. Kendall/Hunt Publishing Company, USA.

Fortmann, L. 1995. Woodsman, woodsman, listen to me: the people and the forestry profession. In K.M. McClain and C.P McClary (eds.). Exploring Multiple Use and Ecosystem Management: From Policy to Operational Practices. FAO/ECE/ILO Proceedings of International Forestry seminar, September 9-15, 1995. Prince George, British Columbia, Canada. pp. 69-75.

Grima, A.P. 1985. Participatory rites: integrating public involvement in environmental impact assessment. Environmental Monogram No. 5 .

Grumbine, R.E. 1994. What is ecosystem management? Conservation Biology 8(1): 27-38.

Harris, T.A. 1967. I'm OK, You're OK: a practical guide to transactional analysis. Harper and Row, New York.

Jones, M.L. and L.A. Greig. 1985. Adaptive environmental assessment and management. In V.W. Maclaren and B. Whitney (eds.). New 
directions in environmental impact assessment in Canada. pp. $21-42$ Methuen Publications, Toronto.

Kessler. W. 1995. Getting our forests acts together: forest practices, policy, and science. In K.M. McClain and C.P McClary (eds.). Exploring Multiple Use and Ecosystem Management: From Policy to Operational Practices. FAO/ECE/ILO Proceedings of International Forestry seminar, September 9-15, 1995. Prince George, British Columbia, Canada. pp. 231-237.

Kohm, K.A. and J.F. Franklin (eds.). 1997. Introduction. In K.A. Kohm and J.F. Franklin (eds.). Creating a Forestry for the 21st Century. pp 1-5. Island Press, Washington, D.C.

Krawetz, N.M., W.R. McDonald and P. Nichols. 1987. A framework for effective monitoring. Canadian Environmental Assessment Research Council, Ministry of Supply and Services, Ottawa. Leuschner, W.A. 1990. Forest regulation, harvest scheduling, and planning techniques. John Wiley \& Sons, Inc., Toronto.

McDougall, F.W. 1986. Forest management in Alberta. Burgess-Lane memorial lecture. University of British Columbia. January 16, 1986. ENR No. I/144. Alberta Energy and Natural Resources, Edmonton. McLean Creek Advisory Committee. 1996. McLean Creek timber harvesting plan: terms of reference. Spray Lake Sawmills (1980) Ltd. Alberta.

McLean Creek Advisory Committee. 1997. McLean Creek timber harvesting plan: resource management policy. Spray Lake Sawmills (1980) Ltd. Alberta.

McLean Creek Advisory Committee. 1998. McLean Creek timber harvesting plan: harvest design. Spray Lake Sawmills (1980) Ltd. Alberta.

Meidinger, E.E. 1997. Organizational and legal challenges for ecosystem management. In K.A. Kohm and J.F. Franklin (eds.). Creating a Forestry for the 21st Century. pp. 357-379. Island Press, Washington, D.C

Mitchell, B. 1997. Resource and environmental management. Addison Wesley Longman Limited, England.

Moote, M.A. and M.P. McClaran. 1996. Viewpoint: implications of participatory democracy for public land planning. Journal of Range Management 50: 478-481.

Natural Resources Canada. 1997. The state of Canada's forests. $8^{\text {th }}$ Report to Parliament. Canadian Forest Service, Ottawa.

Nixon, B. 1993. Public participation: changing the way we make forest decisions. In K. Drushla, B. Nixon and R. Travers (eds.). Touch Wood: B.C. Forests at the Crossroads. pp. 23-66. Harbour Publishing, Meridian Park.
Opio, C. 1989. Forest management planning: West Bragg Creek case study. Faculty of Environmental Design, University of Calgary. O'Shea, K. 1993. Wildland/Urban interface. Unit III. Fire in Resource Management Workshops (March 1-11, 1993), Forest Technology School, Hinton, Alberta.

Perry, D.A. and M. Amaranthus. 1997. Disturbance, recovery, and stability. In K.A. Kohm and J.F. Franklin (eds.). Creating a Forestry for the 21st Century. pp 31-56. Island Press, Washington, D.C.

Phillips, C.S. 1985. Secrets of successful publications. Prentice-Hall, New York.

Roberts, R. 1988. Public involvement: planning and implementing public involvement programmes. Praxis, Calgary, Alberta.

Schmeigelow, F.K.A. and S. Hannon. 1993. Adaptive management, adaptive science and the effects of forest fragmentation on boreal birds in northern Alberta. In R.E. McCabe and K.A. Glidden (eds.). Transactions of the 58th North American Wildlife and Natural Resources Conference. pp. 584-598.

Sedjo, R.A. 1995. Ecosystem management: an uncharted path for public forests. Resources 121(10): 18-21.

Slocombe, D.S. 1993b. Implementing ecosystem-based management: development of theory, practice, and research for planning and managing a region. BioScience 43(9): 612-22.

Slocan Forests Products Ltd. 1998. Bonanza Face ecosystem design. Slocan, B.C.

Taylor, B., L. Kremsater, and R. Ellis. 1997. Adaptive management of forests in British Columbia. BC Ministry of Forests, Victoria. Thompson, D. and L. McKay. 1984. Management problems in/and environmental science. Faculty of Environmental Design, University of Calgary.

USDA Forest Service. 1978. Public involvement: beginnings in the northern region. Mitchell Press, Northern Information Service.

Walters, C.J. and R. Hilborn. 1978. Ecological optimization and adaptive management. Annual Review of Ecological Systems 9: 157-88. Walters, C.J. and C.S. Holling. 1990. Large-scale experiments and learning by doing. Ecology 71: 2060-2068.

White, J.D., D. DeBell, M. Amaranthus, and B. Woodard. 1994. Demonstration of ecosystem management options (DEMO): a cooperative effort between NFS and research in the Pacific Northwest. 